TITLE:

\title{
The personal cost of dementia care in Japan: A comparative analysis of residence types(Abstract_要旨)
}

$\operatorname{AUTHOR}(\mathrm{S})$ :

Nakabe, Takayo

\section{CITATION:}

Nakabe, Takayo. The personal cost of dementia care in Japan: A comparative analysis of residence types. 京都大学, 2020, 博士(社会健康医学)

\section{ISSUE DATE:}

2020-03-23

URL:

https://doi.org/10.14989/doctor.k22382

\section{RIGHT:}

Accepted Version. The owner licences back the following rights to the Contributor in the version of the Contribution that has been peer-reviewed and accepted for publication, but not the final (the "Accpeted Version"). The version posted may not be updated or replaced with the final published version (the Version of Record). 


\begin{tabular}{|l|l|c|c|}
\hline 京都大学 & 博士 (社会健康医学) & 氏 名 & 中 部 貴 央 \\
\hline 論文題目 & $\begin{array}{l}\text { The personal cost of dementia care in Japan: A comparative analysis of } \\
\text { residence types } \\
\text { (認知症ケアに関する個人の経済的負担 : 日本における居住形態別の比較) }\end{array}$
\end{tabular}

(論文内容の要旨)

【背景・目的】

日本では超高齢社会の進展に伴って認知症の高齢者が増加しており、そのケアの供給が 社会的課題である。認知症のケアは、介護保険サービスによるフォーマルケアだけでなく、 介護保険外サービスの活用や、主に家族等による自主的な介護を中心としたインフォーマ ルケアにより成り立っているため、この両者を併せた負担を把握する必要がある。また、 地域包括ケアシステム実現のために、自宅や介護保険施設以外にも、サービス付き高齢者 向け住宅や有料老人ホームなど、高齢者の住まいのあり方が多様化するが、認知症ケアの 経済的負担について在宅介護と施設入居を比較した研究は世界的にも少なく、本邦では見 つからない。そこで、本研究では、認知症ケアにおける個人レベルの経済的負担を可視化 し、居住形態別に比較することを目的とした。

\section{【方法】}

本研究はインターネット質問票調査による横断研究である (2016 年 3 月 4 日〜 14 日実 施)。30 歳以上の介護者を対象とし、3600 名を目標人数とした（30 代 - 40 代 · 50 代 60 代:各 850 名、70 代以上:200 名)。質問票は、Resource Utilization in Dementia (RUD) 3.0 version に、日本の医療・介護制度に合わせた質問項目を追加した。質問票の項目は、 （1）認知症の人の属性、（2）介護者の属性、（3）介護者の職務状況およびインフォーマ ルケア、(4) 医療・介護サービスの利用状況の 4 領域、全 40 項目である。認知症ケアの 経済的負担は、インフォーマルケアコスト、介護費自己負担額（保険適用・保険外）、医 療費自己負担額の合計とし、インフォーマルケアコストは、機会費用法に基づき 1 日あた りのインフォーマルケア時間、性別・年齢階層別平均賃金を用いて算出した。経済的負担 の居住形態別の比較には、性・年齢・要介護度で調整した実測值と予測值（平均值）の比 （OE 比）を用いた。

【結果・考察】

3916 名の回答のうち、矛盾回答を除いた 3841 名を解析対象とした。インフォーマル ケアコストに関する OE 比はグループホームで最も低く（0.32）、在宅で最も高かった (1.31)。医療費・介護費の自己負担額に関する $\mathrm{OE}$ 比は在宅が 0.73 であったが、施設入 居の場合は 1.08-1.70 と高く、とくに有料老人ホームの場合が高かった（1.70）。施設入 居の場合にもインフォーマルケアは提供されており、いずれの居住形態でも個人レベルの 経済的負担は 1 か月あたり 16〜26 万円であり、経済的負担全体の OE 比の範囲は縮小し た（0.72-1.11）。介護保険外サービスも含めた介護費自己負担額では、おむつなどの消耗 品や施設入居費用、食費などへの負担が大きい意見も挙げられた。とくに在宅介護のみな らず、制度上「自宅」として扱われるサービス付き高齢者向け住宅や有料老人ホームでは、
インフォーマルケアも含めて経済的負担が大きい可能性が示唆された。本研究は、インターネッ 卜調査会社のモニターを用いて大規模な対象を確保することができたが、非確率的な標本抽出の ため代表性に限界がある。また、介護者自身の精神的負担（介護負担感等）は把握できておらず、 認知症ケアの負担を主観的・客観的の両側面から包括的に把握することが今後の課題である。

【結論】

本研究は日本における認知症ケアについて、インフォーマルケアを含めた経済的負担を明らかに し、居住形態別に比較した。インフォーマルケアコストを含めた場合、居住形態間の経済的負担 の差が縮小した。在宅介護は施設入居と比較してインフォーマルケアコストが高く、医療・介護 サービスへの自己負担額は低くとも、経済的負担全体が高い傾向にあった。本研究の成果は、個 人および社会的経済負担を考慮した持続可能な認知症ケアのあり方を探索する上で政策的な一 助となる。

(論文審査の結果の要旨)

本研究は、日本における認知症ケアの経済的負担について、個人レベルで、居住形 態別に定量化した。認知症ケアの経済的負担は、医療費介護費の自己負担額と、国際 標準的な測定方法によりインフォーマルケアコストを算出した。実測值と予測值（平 均值）の比を用いて、認知症の人の性・年齢・要介護度で調整し、経済的負担を居住 形態別に比較した。その結果、在宅介護では医療費介護費の自己負担額は低いが、イ ンフォーマルケアコストを含めた場合に、医療費が高い療養型病床や、入居費などの 介護保険外サービス利用費が高い有料老人ホームと同程度に、経済的負担が高いこと が示された。

インターネット質問票調查を用いた非確率的な標本抽出のため代表性に限界がある が、主たる介護者の回答が少ない場合に介護寄与割合による調整を行い、主たる介護 者として扱った。また、要介護度を臨床的重症度指標の代替指標として必要な介護量 を把握した。本研究は国際標準的質問票を用いた大規模サンプルを対象とし、認知症 ケアの経済的負担を在宅介護と多様な居住形態を比較した研究として国内外で初めて 示した知見である。本研究結果は、地域内における在宅ケアと施設ケア、フォーマル ケアとインフォーマルケアのバランスの考察に貢献しうる結果といえる。

以上の研究は認知症の人のケアの経済的負担の解明に貢献し、超高齢社会における持続可能 な認知症ケアのあり方に関する政策に寄与するところが大きい。

したがって、本論文は博士（社会健康医学）の学位論文として価值あるものと認める。 なお、本学位授与申請者は、令和元年 12 月 19 日実施の論文内容とそれに関連した試問を 受け、合格と認められたものである。 